Al leaves his wife Eva, son Stefan and daughter Vera. He leaves us missing his impish challenges to academic and bureaucratic pomposity and the infectious laugh that marked his conversations with so many generations of students.

Arlene W. Saxonhouse University of Michigan

William Zimmerman University of Michigan

\section{Abramo Fimo Kenneth Organski}

Abramo Fimo Kenneth Organski, professor of political science and senior research scientist, Center for Political Studies, passed away on March 6 in Denver, Colorado. He was 74 and lived in Ann Arbor, Michigan. The cause of death was a heart attack.

Dr. Organski's work on the impact of economic growth on international conflict led to pioneering research on the causes of major wars and on the relationship between the organization of governments and governments' ability to mobilize resources to achieve policy objectives.

Dr. Organski was born in Rome in 1923, where he attended the Ginnasio Liceo Torquato Tasso. He came to the United States with his parents, Menasce and Anna (Feinstein) Organski, and his brother, Guido, in 1939, when his family fled the anti-Jewish laws of the Musolini regime. He settled in New York, where he became an American citizen in 1944. He served with the American armed forces from 1943 to 1945 , and went on to earn a B.A. (1947), M.A. (1948), and Ph.D. (1951) from New York University. After teaching at Brooklyn College from 1952 to 1964 , he joined the faculty of the University of Michigan in 1965 , where he remained until his death. He became a senior research scientist in the Institute for Social Research in 1969.

$\mathrm{He}$ also served as a visiting professor at Columbia University, The Fletcher School of Law and Diplomacy, and the University of Pennsylvania, as well as visiting professor or scholar in residence at the Agnelli Foundation in Italy and the Univer- sities of Turin, Catania, and Florence. He was honored as a guest of the University of Bologna on the occasion of that university's 900th anniversary and was awarded the Cavaleri dela Republica by the government of Italy.

His books included World Politics; Population and World Power, coauthored with his first wife, Katherine Davis Fox; Birth, Death and Taxes, written with several of his students; Stages of Political Development; The War Ledger, written with Jacek Kugler; and The Thirty-Six Billion Dollar Bargain.

In 1981, Professor Organski, together with Drs. Jacek Kugler and Bruce Bueno de Mesquita, founded New York-based Policon Corporation, now known as Decision Insights, Inc., to assist the United States government and private corporations in conducting complex negotiations and resolving disputes.

At the time of his death, Kenneth was chairman of the Board of Directors of Decision Insights. His intellectual accomplishments won him numerous honors at the University of Michigan, including the Distinguished Faculty Achievement Award. In 1992, he was given a lifetime achievement award by the American Political Science Association's Organized Section on Conflict Processes for his contributions to the study of international conflicts. He had previously been a Social Science Research Council Fellow and a Fulbright Fellow.

Kenneth will be remembered not only for his intellectual depth and originality, but also for his ebullience, love of language, human warmth, and gift for friendship. $\mathrm{He}$ was a devoted husband, father, and grandfather, and will be deeply mourned by his wife, Patricia Joan Bard; his daughter, Elizabeth Anna Organski-Horn, and her husband, Steven Horn of Whitmore Lake, Michigan; his son, Eric Fox Organski of Savannah, Georgia; his grandson, Steven Horn Jr.; his brother, Guido Organski of Litchfield, CT; and generations of devoted students. John E. Jackson University of Michigan

\section{Myron Weiner}

Myron Weiner, Ford International Professor of Political Science at MIT, the nation's leading authority on Indian political studies and a specialist in the fields of political development, political demography, migration, ethnic conflict, and child labor, died in his Vermont home on June 3, 1999, of a brain tumor, which was first diagnosed in December. He was born in New York City in 1931, graduated Phi Beta Kappa from City College of New York in 1951, and received his advanced degrees from Princeton in 1955 . He taught at Princeton and Chicago before coming to MIT in 1961 . He had visiting appointments at Harvard, Oxford, Hebrew University, Delhi University, and the University of Paris. He was elected a member of the American Academy of the Arts and Sciences and the American Philosophical Society.

Myron was a master of empirical field research, and especially the art of interviewing officials and common citizens. He was genuinely excited whenever he found that a logically coherent and theoretically significant train of cause and effect relationships had been matched by substantial case evidence. He had no vested interest in any particular grand theories, but rather sought answers to clearly formulated questions. He was also an inspiring mentor to graduate students who are now the next generation of leaders in both Indian studies and political development work. He was an equally creative academic administrator, serving as head of the political science department from 1974 to 1977, and as director of the MIT Center for International Studies from 1987 to 1992.

A prolific writer, Myron authored 13 books and was the editor or coauthor of 19 others. Even as his strength was giving out, he completed a final monograph. His professional knowledge was greatly appreciated by governments: $\mathrm{He}$ served as consultant to the Department of State, the National Security Council, the Agency for International Development, the World Bank, and since 1996 he was chairman of the advisory committee to 
the United Nations High Commission for Refugees (UNHCR).

For all of his efficiency and effectiveness, Myron was a gentle and generous person who always had the time and patience to listen to others and to help them with their problems. He was constantly engaged in long phone conversations with friends and people who needed assistance. His skills as an administrator were much like his skills as a researcher in that he had a remarkable ability to identify with great clarity the essential problem and to seek out the appropriate data and evidence necessary for arriving at sound plans for action. Yet, he was always suspicious of too-neat solutions or explanations. As a researcher, he was quick to challenge the conventional wisdom and to ask the awkward question; as an admisistrator, he was equally quick to cut through confusion and to move directly to appropriate action. He was totally immune to procrastination. $\mathrm{He}$ was a master at delegating responsibilities because he could evaluate in an even-handed and objective way the personal strengths and weaknesses of others.

As a person, Myron had a great sense of style and a truly adventurous spirit. Once, as he headed on research leave to India, he didn't do the ordinary and book airline tickets. Rather, he picked up a car in Europe and drove his family overland, following in part Alexander the Great's route. In doing the Silk Road, he went through Xinjiang into Pakistan on the Karakoram highway. During his last illness, between chemotherapy treatments, he fulfilled a promise to his wife Sheila to take her on safari in South Africa. He was the loving owner of a series of handsome dogs-several collies, an Afghan hound, and a Standard (read "giant") poodle-that would often accompany him to his office. He was an enthusiastic cook and a selftaught connoisseur of wines. His trademark was his bow ties.

As an area specialist of the developing countries, and of India in partricular, Myron had great respect for indigenous cultures, but he was
We and others wish to express our deepest sympathies to our colleague Peter Gourevitch and to Alex and Nick Gourevitch on the untimely loss of his wife and their mother, Lisa Hirschman. In her honor, the Lisa Hirschman Memorial Fund has been created at the Preuss School to support psychological counseling services for students and their families.

Suzanne Berger, Peter Cowhey, Paul Drake, Joanne Gowa, Nancy Gilson, Stephan Haggard, Miles Kahler, Robert Jervis, Mary Fainsod Katzenstein, Peter Katzenstein, Nannerl Keohane, Robert Keohane, Steven Krasner, Arend Lijphart, Sam Popkin, Ronald Rogowski, Susan Shirk, and Janice Stein.

\section{in honor of}

\section{Lisa Hirschman \\ October 17, 1946 - May 11, 1999}

Lisa Hirschman received a B.A. from Barnard College, a M.A. in Latin American Literature from the University of Wisconsin, and a Ph.D. in counseling psychology from Boston University. She practiced as a psychotherapist for over twenty years in Boston, Montreal, and San Diego. She began her career working with children from disadvantaged backgrounds and went on to publish pioneering work on sexual abuse and on "detailing" in self-psychology approaches to psychotherapy. She is survived by her husband Peter Gourevitch, professor of political science at the University of California, San Diego, co-editor of International Organization, former co-Program Chair of the APSA Annual Meeting (1993), and founding Dean of the Graduate School of International Relations and Pacific Studies (UCSD); by her two sons, Alex(21) and Nick (18), her parents Albert O. and Sarah Hirschman of Princeton, and her sister, Katia Salomon of Paris, France.

The Memorial Fund is an endowment at the Preuss School @ UCSD, a public charter junior and senior high school, created through UCSD campus initiatives, strongly supported by Dr. Hirschman and in which her husband Peter Gourevitch has been active.

Those wishing to make a contribution should make checks payable to UCSD Foundation and designate in the memo section: Lisa Hirschman Fund. Contributions should be sent to:

$$
\begin{gathered}
\text { UCSD Foundation, } \\
\text { University of California, San Diego } \\
9500 \text { Gilman Drive } \\
\text { La Jolla, CA } 92093-0940
\end{gathered}
$$


never an apologist for questionable practices or harmful policies. His prime commitment was always to finding the appropriate facts and presenting them in a context that would explain the movement of history. He also, however, had strong and refined moral and social instincts. He believed that in addition to advancing basic knowledge, research should and could help improve the world by showing the way to human betterment. For example, he shocked the Indian establishment with his Princeton Press book, The Child and the State in India, by showing that it was not poverty that caused child labor and illiteracy, but rather, as he showed to be the case in other countries, it was the other way around, and that overcoming illiteracy was what would reduce poverty. He fearlessly suggested that India had a special problem because the caste system led people to think that lower-caste childre were destined for menial jobs and, hence, did not need reading skills. He went further and noted that Hinduism, lacking the tradition of the sacred Book, which Christianity, Jusaism, and Islam have, had no built-in compulsion to make its believers into readers.

Myron was one of the early thinkers on the problems of democracy in newly independent states. His award-winning Party Building in a New Nation, detailed how the Con- gress Party operated in five districts to insure popular participation and to accommodate local interests and thereby reduce social tensions in the whole country. He was deeply involved in the comparative study of electoral behavior in developing countries. As much as he valued democracy, he also clearly saw that modernization rather than eroding ethnic and religious identities could strengthen such loyalties and, thus, intensify internal conflicts. He documented the problems of ethnic conflict in Sons of the Soil.

In more recent years, he focused on the problems of political demography and population movements, both domestically and internationally. Myron was one of the first to recognize that the post-Cold War would be characterized by heightened forces of both globalization and localization, and that the contradictory pressures would produce intensified conflicts. He went to great trouble interviewing people to find out why they moved and what their ethnic identities meant to them. In advising the UNHCR, he argued that the policy of focusing on support for refugees and immigrants in the receiving country should be balanced by giving more attention to reducing the causes of emigration in the sending countries.

At the time of his death, Myron was engaged in three major research projects. The first was a collabora- tive study of policies toward immigration, refugees, illegal migration, and citizenship in Japan, Germany, South Africa, and the United States. The second was an analysis of the conditions that generate migration and refugee flows and the policy instruments available to receiving countries and international institutions to ameliorate those conditions.

The third was an expanded study of child labor in developing countries. Part of Myron's great success in collaborative research was that he had the knack of being able to restate the ideas of others so as to restructure and refine them. In the end, however, he always gave credit where credit was due by graciously insisting that the refined idea still belonged to the other party. Myron constantly demonstrated this skill in his role as the guiding spirit of JOSPOD (Joint Harvard-MIT Seminar on Political Development) that has just completed its 35 th year.

Myron will be sorely missed by his friends, colleagues, collaborators, and former students, and his death is a true loss to political science, for he had many more years of creative research planned. His former students, Ashutosh Varshney and Paul Brass, have organized a festschrift volume, and MIT will hold a memorial service for him on November 8 . Lucian W. Pye MIT 